\title{
Outbreak of scrub typhus in odisha - an emerging threat
}

\author{
SK Pattnaik*, B Ray, S Sinha, A Mohanty, S Sahu \\ From ESICM LIVES 2015 \\ Berlin, Germany. 3-7 October 2015
}

\section{Introduction}

Scrub typhus a zoonotic disease, caused by the intracellular parasite Orienta tsutsugamushi, transmitted by the bite of trombiculid mite. It is under reported in Odisha, may be due to lack of suspicion and / lack of specific diagnostic test.

\section{Objectives}

To describe the diverse clinical and laboratory manifestations of scrub typhus patients admitted into the adult tertiary critical care unit at Apollo Hospitals, Bhubaneswar.

\section{Methods}

All cases of febrile illness diagnosed as scrub typhus over a period of 9months from June 2014-Feb 2015 were analyzed. Diagnosis was based on the presence of the eschar and /or positive by IgM enzyme-linked immunosorbent assay (Sensitivity $93 \%$ and specificity $98 \%$ ).

\section{Results}

During the study period 40 cases of scrub typhus were detected and most of them presented with fever (100\%), headache $(80 \%)$, cough and dyspnea (65\%). Eschar was detected in $12 \%$ cases. Mechanical ventilation (Invasive$18.5 \%$, Non-invasive-81.5\%) applied in $65 \%(\mathrm{n}=26)$ cases. All patients were managed with either doxycycline $(\mathrm{n}=13$; $32.5 \%)$ or doxycycline with azithromycin $(n=27 ; 67.5 \%)$. Among the patients $92.5 \%(\mathrm{n}=21)$ survived and $7.5 \%$ $(\mathrm{n}=3)$ died.

\section{Conclusions}

Scrub typhus has emerged as an important cause of febrile illness in Odisha. Empirical treatment with doxycycline is justified in endemic areas.

\footnotetext{
Apollo Hospitals, Bhubaneswar, India

\section{SpringerOpen $^{\odot}$}

(C) 2015 Pattnaik et al.; This is an Open Access article distributed under the terms of the Creative Commons Attribution License (http:// creativecommons.org/licenses/by/4.0), which permits unrestricted use, distribution, and reproduction in any medium, provided the original work is properly cited.
Published: 1 October 2015

doi:10.1186/2197-425X-3-S1-A355

Cite this article as: Pattnaik et al:: Outbreak of scrub typhus in odisha an emerging threat. Intensive Care Medicine Experimental 2015 3(Suppl 1):A355.
Submit your manuscript to a SpringerOpen ${ }^{\circ}$ journal and benefit from:

- Convenient online submission

- Rigorous peer review

- Immediate publication on acceptance

- Open access: articles freely available online

- High visibility within the field

- Retaining the copyright to your article

Submit your next manuscript at $>$ springeropen.com 